\title{
Kandungan Pestisida Organoklorin dalam Air Susu Ibu di Daerah Pertanian Bawang Merah Kabupaten Brebes
}

\author{
Dwi Cahyaningrum*), Hanifa Maher Denny ${ }^{* *}$, M.Sakundarno Adi**) \\ *) Magister Promosi Kesehatan Universitas Diponegoro Semarang \\ Korespondensi siduik@gmail.com \\ **) Fakultas Kesehatan Masyarakat, Universitas Diponegoro, Semarang.
}

\begin{abstract}
ABSTRAK
Pestisida organoklorin digunakan secara luas di pertanian pada waktu yang lampau. Zat ini mempunyai sifat persisten di lingkungan, memiliki kemampuan bioakumulasi dan biomagnifikasi dalam rantai makanan. Paparan organoklorin pada bayi sebelum lahir dapat menyebabkan kelahiran premature, abortus spontan, bahkan berdampak mengganggu fungsi system syaraf pusat. Wanita di daerah pertanian bawang merah beresiko tinggi terhadap paparan pestisida baik dari keterlibatan mereka di pertanian maupun paparan dari lingkungan. Air susu ibu adalah media yang sesuai untuk memantau paparan organoklorin pada manusia. Penelitian ini bertujuan untuk mengetahui kandungan pestisida organoklorin pada air susu ibu di daerah pertanian bawang merah Kabupaten Brebes, keterlibatan wanita di pertanian, dan keterkaitan beberapa faktor dengan konsentrasi organoklorin. Metode dan desain penelitian yang digunakan adalah deskriptif kualitatif dengan pendekatan cross sectional, dengan responden berjumlah 14 orang. Hasil penelitian menunjukkan sebanyak 4 responden mempunyai $p$ 'pDDE dengan konsentrasi $>0,01 \mathrm{mg} / \mathrm{kg}(0,018-0,082 \mathrm{mg} / \mathrm{kg})$ dan 11 responden mempunyai dieldrin dengan konsentrasi $<0,01 \mathrm{mg} / \mathrm{kg}(0,001-0,007 \mathrm{mg} / \mathrm{kg})$. Semakin meningkat nomor kelahiran, tingkat pengetahuan dan praktek penggunaan pestisida konsentrasi p'pDDE cenderung menurun. Kebiasaan makan ikan yang tercemar menjadi sumber paparan organoklorin pada wanita di daerah pertanian bawang merah Kabupaten Brebes. Kebijakan pengawasan penggunaan pestisida yang sekarang ada belum efektif untuk meningkatkan keamanan bekerja dengan pestisida pada petani.

Kata Kunci : Organoklorin, ASI dan Keamanan bekerja dengan pestisida
\end{abstract}

\begin{abstract}
THE CONTENT OF ORGANOCHLORINE PESTICIDES IN HUMAN BREAST MILK IN ONION AGRICULTURA AREA AT BREBES DISTRICT; Organochlorine pesticides were widely used in agricultural at the past, these compounds are persistent in the environment and can be bioaccumulate and biomagnificate in food chain. Prenatal organochlorine exposure may lead to premature birth, spontaneous abortion and infere central nervous system function. Women living in agriculture area pose high risk of pesticides exposure resulting from their agriculture occupation and environment exposure. Breast milk could be a suitable matrix for monitoring organochlorine exposure in human. This study aimed to assess the content of organochlorine pesticides in human breast milk, women involvement in agricultural activity and factors related to the level of organochlorine compounds in breast milk. The qualitative descriptive method using cross sectional approach was applied in this research. There were 14 partisipants. The result demonstrated that 4 partisipans had p'pDDE level above $0,01 \mathrm{mg} / \mathrm{kg}$ (0,018-1,082), and 11 partisipans had level of Dieldrin below 0,01 mg/kg (0,001-0,007). Concentration p'pDDE tend to decreased as the increased of parity, level of knowledge, and level practices of pesticide. Dietary habits especially fish consumption was considered as a source of organochlorine exposure to human. Supervision policy the used of pesticide hasn't effective yet to increase safe practices of pesticides among farmers.
\end{abstract}

Keywords : : Organochlorine, breast milk, safe practices of pesticides 


\section{PENDAHULUAN}

Profil kesehatan Kabupaten Brebes tahun 2015 menyebutkan bahwa angka kematian bayi dan Berat Bayi Lahir Rendah di Kabupaten Brebes terus meningkat dari tahun 2011-2015. Sebagai daerah penghasil bawang merah di tingkat nasional jumlah penduduk diatas usia 15 tahun di Kabupaten Brebes paling banyak bekerja di sektor pertanian yaitu sebesar $40 \%$. Pekerjaan di pertanian tidak hanya dilakukan oleh lakilaki tetapi juga oleh kaum wanita sebesar $40 \%$ dari jumlah pekerja pertanian yang ada. Wanita yang terlibat di pertanian bawang merah sangat rentan terhadap paparan pestisida yang digunakan secara intensif untuk mendukung sektor pertanian yaitu untuk membunuh hama. Salah satu jenis pestisida yang digunakan di pertanian bawang merah Kabupaten Brebes adalah organoklorin (Pemprov Jateng, 2015).

Organoklorin merupakan pestisida yang bersifat persisten dapat terbioakumulasi di alam serta bersifat racun pada manusia dan makluk hidup lainnya. Organoklorin bersifat tidak reaktif, stabil, memiliki kelarutan yang sangat tinggi dalam lemak dan memiliki kemampuan degradasi yang rendah. Paparan jangka panjang pestisida organoklorin dapat mempengaruhi fungsi hati, gangguan system endokrin, perkembangan motorik dan mental, gangguan system kekebalan dan syaraf, resiko pada payudara, jantung, kanker prostat, leher rahim dan sakit perut. Paparan pestisida organoklorin pada bayi sebelum lahir dapat menyebabkan kelahiran premature, abortus spontan, dan menggangu fungsi system syaraf pusat (Timothy, Brian, 2004).

Paparan pestisida organoklorin telah dipelajari dalam beberapa penelitian pada pekerja yang terpapar akibat pekerjaan dan populasi umumnya dengan mengukur komposisi pestisida dalam darah, urine, jaringan adipose dan air susu ibu. Air susu ibu dengan kepekatan lemak yang relatif tinggi, adalah sampel yang cocok dan indikator terbaik untuk mempelajari paparan jangka panjang pestisida organoklorin karena mudah untuk dilakukan, dapat dikumpulkan secara non-invasif dan menunjukkan tingkat pencemaran pada lemak yang matang. Konsentrasi organoklorin dalam air susu ibu dapat digunakan untuk mengetahui adanya pestisida organoklorin di lingkungan. Pestisida yang dapat diidentifikasi dalam air susu ibu diantaranya adalah isomer $\mathrm{HCH}(\alpha$ $\mathrm{HCH}, \quad \beta \mathrm{HCH}$, gamma HCH), DDT $\left(p, p^{\prime} D D T, \quad o, p^{\prime} \quad D D T\right), \quad D D E \quad\left(p, p^{\prime} D D E\right.$, $o, p$ 'DDE), Heptachlore dan metabolitnya Heptachlore -epoxide, Aldrin dan metabolitnya yaitu Dieldrin. Ekskresi sisa pestisida dalam Air Susu Ibu dipengaruhi oleh beberapa faktor seperti paritas, umur, kebiasaan makan, habitat dan beberapa faktor eksternal lainnya (Mirsha, Bedi, 2013).

Pada survey awal yang dilakukan melalui pengamatan dan wawancara dengan 
bidan dan kader kesehatan di Kecamatan Wanasari Kabupaten Brebes, sebagian besar pekerja yang terlibat pasca panen bawang merah adalah wanita dengan umur 24-40 tahun. Mereka memilah, mengikat dan membersihkan daun bawang tanpa memakai alat pelindung diri. Kegiatan tersebut ada yang dilakukan dilingkungan rumah seperti teras dan pekarangan. Wanita juga terlibat pada saat proses menanam dan pemeliharaan tanaman bawang merah di sawah.

Berdasarkan waktu paruhnya, penggunaan organoklorin pada waktu yang lampau meninggalkan residu pada lingkungan yang berpotensi menjadi ancaman pada kesehatan masyarakat khususnya pada wanita yang terlibat di pertanian bawang merah. Pemeriksaan kolinesterase untuk mendeteksi keracunan pestisida karbamat dan organofosfat pada wanita usia subur di Kabupaten Brebes telah banyak dilakukan, sedangkan pemantauan organoklorin dalam air susu ibu di pertanian bawang merah Kabupaten Brebes belum banyak ditemukan.

Berdasarkan uraian diatas peneliti ingin mengetahui lebih jauh kandungan pestisida organoklorin dalam Air Susu Ibu di daerah pertanian bawang merah Kabupaten Brebes. Dalam penelitian ini diambil air susu Ibu yang bekerja di pertanian dan air susu ibu yang tidak bekerja di pertanian untuk menggambarkan faktor resiko paparan pestisida organoklorin pada wanita di daerah pertanian bawang merah Kabupaten Brebes.

\section{METODE}

Penelitian ini menggunakan desain deskriptif kualitatif dengan pendekatan cross sectional, dengan responden berjumlah 14 orang. Pemilihan responden dilakukan secara purposive sampling dengan menggunakan kriteria-kriteria tertentu. Pada penelitian ini diambil sampel $100 \mathrm{ml}$ Air Susu Ibu yang terlibat di pertanian dan tidak terlibat di pertanian untuk diuji pestisida organoklorin $H C H(\alpha H C H, \beta H C H$, gamma HCH), DDT (p,p'DDT, o,p' DDT), DDE (p,p'DDE, $o, p$ 'DDE), Heptachlore dan metabolitnya Heptachlore -epoxide, Aldrin dan metabolitnya yaitu Dieldrin. Pengujian ASI dilakukan dengan ekstraksi lemak dan pembacaan menggunakan gas kromatografi di laboratorium dengan akreditasi internasional. Setelah didapatkan sampel ASI positif mengandung pestisida organoklorin $>0,01 \mathrm{mg} / \mathrm{kg}$ maka penelitian dilanjutkan dengan metode kualitatif. Penelitian kualitatif digunakan untuk mengeksplorasi riwayat paparan pestisida dan mengeskplorasi paparan organoklorin pada waktu lampau dengan informan utama adalah responden dengan konsentrasi $p^{\prime} p D D E \quad>0,01 \mathrm{mg} / \mathrm{kg}$ dan informan triangulasi yaitu bapak atau ibu informan utama dan juga tokoh masyarakat. 
HASIL DAN PEMBAHASAN

Berdasarkan hasil penelitian menunjukkan residu organoklorin yang terdeteksi pada 14 sampel ASI adalah p'pDDE dan Dieldrin. p'pDDE terdeteksi dengan konsentrasi diatas $0,01 \mathrm{mg} / \mathrm{kg}(0,018$ $0,082 \mathrm{mg} / \mathrm{kg}$ ) dari sampel ASI wanita yang terlibat di pertanian dan dieldrin terdeteksi dengan konsentrasi dibawah $0,01 \mathrm{mg} / \mathrm{kg}$ $(0,001-0,007 \mathrm{mg} / \mathrm{kg})$ dari sampel ASI wanita yang terlibat dan tidak terlibat di pertanian. Organoklorin DDT (o'pDDT dan p'pDDT), Aldrin, $\mathrm{HCH}$ ( $\alpha \mathrm{HCH}, \beta \mathrm{HCH}$, gamma $\mathrm{HCH}$ ) ( $\alpha \mathrm{HCH}, \beta \mathrm{HCH}$, gamma HCH) dan Heptachlore epoxide tidak terdeteksi.

$p, p ' D D E$ adalah metabolite dari $p, p D D T$, hasil ini menunjukkan bahwa $D D T$ digunakan di daerah pertanian Kabupaten Brebes pada masa lalu dan terbioakumulasi di dalam tubuh responden dalam jangka waktu yang lama. Di dalam tubuh, DDT dimetabolisme menjadi $D D E$ dan tetap tinggal dalam jangka waktu lebih lama dalam jaringan adipose dibandingkan $D D T$. Waktu paruh $D D T$ dalam tubuh adalah lebih dari 6 tahun, dan waktu paruh $D D E$ dalam jaringan adipose adalah 7-11 tahun dan terakumulasi dalam jaringan lemak tubuh dengan konsentrasi tinggi (Robson, 2010).

Berdasarkan hasil wawancara mendalam dengan informan triangulasi diketahui bahwa $D D T$ digunakan di pertanian bawang merah desa Tegalgandu pada tahun 1980 - 1990 an. Pada masanya DDT sangat disukai petani karena sifatnya yang lengket dan tahan lama, dengan harga yang murah. DDT sangat efektif untuk membasmi beberapa hama sekaligus sehingga petani tidak perlu mengoplos beberapa jenis pestisida. Beberapa contoh merk DDT di pasaran adalah Bomba, Bison DIDIT, Poudre DDT, X, Ortho.

Hasil penelitian ini sesuai dengan penelitian Denny yang menyatakan bahwa pada tahun 1995-1998 pestisida organoklorin jenis DDT masih dipakai oleh $10 \%$ petani bawang merah di Kabupaten Brebes. Pada penelitian ini $p$ ' $p D D T$ tidak terdeteksi pada 14 sampel ASI responden. Hal ini menunjukkan bahwa tidak ada paparan $D D T$ dalam waktu dekat baik di lingkungan maupun di rantai makanan. Berdasarkan hasil wawancara informan triangulasi menyatakan bahwa pada saat ini DDT sudah tidak keluar di pasaran. Waktu paruh $D D T$ dalam tubuh adalah 6 tahun. Hasil penelitian ini juga didukung oleh Siwiendrayanti bahwa pada focus discussion grup yang dilakukan pada tahun 2010 petani bawang merah di Kabupaten Brebes yang menyatakan bahwa sudah tidak ada yang menjual DDT (Denny, 1999).

Responden menyatakan bahwa keterlibatan wanita di pertanian bawang merah adalah dalam proses menanam benih, pemeliharaan tanaman yaitu membersihkan hama dan rumput liar serta pengolahan hasil panen seperti membersihkan dan memilah 
bawang merah. Tidak ada wanita yang menyatakan membantu menyiapkan, mengoplos, menyemprotkan dan membersihkan peralatan penyemprot pestisida.

Pada saat melakukan aktivitas disawah wanita rentan terpapar pestisida yang disemprotkan petani untuk membasmi hama. Meskipun responden menyatakan jika ada petani yang menyemprot mereka memilih pulang atau berpindah tempat, dan kembali ke sawah jika penyemprotan sudah selesai. $D D T$ yang disemprotkan keudara terbawa angin sampai jauh dan mengenai makhluk hidup yang tidak menjadi sasaran penyemprotan dan selanjutnya mencemari tanah dan lingkungan di sekitarnya. DDT yang menempel pada tanah dan daun bawang akan mengalami penguapan karena adanya panas. Wanita yang sedang berada disawah dapat mengabsorbsi $D D T$ melalui pernafasan meskipun pada saat itu tidak ada penyemprotan. DDT di udara juga ada akibat penguapan dari tanah dan air yang telah tercemar. Siklus penguapan dan penyimpanan terjadi berulang beberapa kali. Setelah disemprotkan ke udara, waktu paruh $D D T$ di atmosfer adalah \pm 1,5-3 hari. Berdasarkan hasil wawancara dengan informan diketahui biasanya petani menyemprot pestisida 2-3 kali dalam satu minggu dengan mencampur beberapa jenis pestisida ( US Public Health Service, 2002).
Aktivitas yang dilakukan petani wanita setelah panen adalah membersihkan dan mengikat daun bawang. Sebagaimana sifat organoklorin yang stabil yaitu tidak terurai oleh pemanasan maupun secara kimia, organoklorin mampu berikatan dengan bahan organik dalam partikel tanah, sisa tanah yang masih menempel pada bawang merah berpotensi masuk kedalam tubuh pekerja wanita apabila tidak diimbangi dengan praktek keamanan bekerja yang baik. Lamanya $D D T$ mengendap di tanah tergantung dari beberapa faktor termasuk suhu, tipe tanah dan kelembaban tanah.

\section{Distribusi umur dan konsentrasi $p$ 'pDDE}

Hasil penelitian menunjukkan responden dengan konsentrasi p'pDDE>0,01 $\mathrm{mg} / \mathrm{kg}$ terbanyak adalah wanita dengan kategori umur 31-36 tahun dengan grafik distribusi umur dan konsentrasi p'p $D D E$ cenderung menurun. Waktu paruh $D D T$ didalam tubuh adalah 6 tahun dan waktu paruh $D D E$ didalam tubuh 7-10 tahun. Pada satu periode waktu paruh konsentrasi $D D E$ dalam tubuh berkurang 50\%. Pada periode 2x waktu paruh konsentrasi $D D E$ dalam tubuh akan terurai sebanyak 75\%. Sehingga semakin bertambah umur ibu konsentrasi p'pDDE semakin berkurang.

\section{Distribusi nomor kelahiran dan konsentrasi $p$ 'pDDE}


Berdasarkan hasil penelitian responden dengan konsentrasi $p ' p D D E>0,01 \mathrm{mg} / \mathrm{kg}$ terbanyak adalah wanita yang menyusui anak pertama dengan grafik distribusi paritas dan konsentrasi p'pDDE cenderung menurun. Hal ini menunjukkan bahwa semakin meningkat nomor kelahiran, konsentrasi p'pDDE cenderung semakin rendah. Hasil penelitian ini sesuai dengan teori yang menyatakan bahwa pada Ibu multipara konsentrasi organoklorin akan lebih sedikit dibandingkan pada Ibu yang menyusui bayi untuk pertama kali. Air susu ibu adalah jalan pengeluaran timbunan organoklorin dalam tubuh. Semakin lama periode menyusui, semakin banyak p'pDDE dapat dikeluarkan dan konsetrasi $p$ 'pDDE semakin menurun (Timothy, 2004).

\section{Distribusi IMT dan konsentrasi $p$ 'pDDE}

Semua responden dengan konsentrasi p'pDDE >0,01 $\mathrm{mg} / \mathrm{kg}$ mempunyai indeks massa tubuh normal dengan grafik distribusi IMT dan konsentrasi p'pDDE cenderung sedikit menurun. Hal ini berarti bahwa semakin tinggi indeks massa tubuh, konsentrasi p'pDDE cenderung semakin rendah. Organoklorin mempunyai sifat larut dalam lemak. Pada paparan yang sama ibu yang lebih gemuk konsentrasi p'pDDE cenderung lebih rendah karena perbedaan perbandingan konsentrasi organoklorin dengan banyaknya lemak tubuh.

\section{Distribusi lama keterlibatan dan konsentrasi p'pDDE}

Berdasarkan hasil penelitian p'pDDE tidak hanya terdeteksi pada wanita dengan masa keterlibatan lebih dari 5 tahun, wanita dengan lama keterlibatan di pertanian kurang dari 5 tahun juga ada yang mengandung p'pDDE lebih dari $0,01 \mathrm{mg} / \mathrm{kg}$. Grafik distribusi lama keterlibatan di pertanian dan konsentrasi p'pDDE cenderung mendatar. Hal ini menunjukkan bahwa perubahan lama keterlibatan di pertanian tidak menyebabkan perubahan konsentrasi $p$ ' $p D D E$. Berdasarkan hasil wawancara diketahui keterlibatan responden secara aktif di pertanian adalah pada tahun 1995-1997. Pada tahun ini DDT digunakan secara intensif di pertanian bawang merah Kabupaten Brebes. Responden lain dengan umur yang sama dan mempunyai lama keterlibatan lebih dari 5 tahun mempunyai konsentrasi $p$ 'pDDE lebih rendah karena terlibat di pertanian pada tahun 2000an dimana penggunaan DDT sudah mengalami penurunan.

Hasil penelitian ini diperkuat oleh penelitian Alfian yang menyatakan bahwa tidak ada hubungan antara lama menjadi petani dengan keracunan pestisida. Hasil ini juga diperkuat oleh teori yang menyatakan bahwa ada beberapa faktor yang menentukan tingkat bahaya ketika terpapar $D D T, D D E$, dan $D D D$ meliputi dosis bahan pencemar yaitu seberapa banyak, lama paparan, dan bagaimana terjadinya kontak 
dengan bahan tersebut (Alfian, 2011,US

Public Health Service, 2002).

\section{Distribusi tingkat pengetahuan dan konsentrasi $p$ 'pDDE}

Berdasarkan hasil penelitian sebagian besar responden dengan konsentrasi $p$ ' $p D D E$ $>0,01 \mathrm{mg} / \mathrm{kg}$ mempunyai tingkat pengetahuan kurang. Grafik distribusi tingkat pengetahuan dan konsentrasi p'pDDE cenderung menurun. Hal ini berarti bahwa semakin tinggi tingkat pengetahuan konsentrasi p'pDDE semakin rendah. Rendahnya tingkat pengetahuan tentang pestisida banyak dihubungkan dengan kejadian keracunan, bunuh diri, resiko paparan, dan tingginya angka kematian di beberapa daerah pertanian di negara berkembang

Hasil penelitian ini didukung oleh Karmini yang menyatakan ada hubungan yang bermakna antara pengetahuan dengan keracunan pestisida pada petani. Petani yang mempunyai pengetahuan kurang memiliki resiko $12,5 \mathrm{x}$ untuk mengalami keracunan daripada petani yang memiliki pengetahuan yang baik (Karmini, 2015).

\section{Distribusi sikap dan konsentrasi p'pDDE}

Sikap responden pada kelompok dengan konsentrasi $p ' p D D E>0,01 \mathrm{mg} / \mathrm{kg}$ adalah sebagian dengan kategori sikap kurang dan sebagian dengan kategori sikap baik. Grafik distribusi sikap dan konsentrasi p'pDDE cenderung mendatar, hal ini menunjukkan bahwa perubahan sikap tidak menyebabkan perubahan pada konsentrasi $p$ 'pDDE.

Kewaspadaan akan bahaya pestisida pada lingkungan dan kesehatan menggambarkan kesadaran melindungi diri dan tanggung jawab pada sekitarnya. Berdasarkan hasil penelitian empat informan triangulasi menyatakan bahwa pestisida itu sangat penting untuk keberhasilan menanam bawang. Sebagaimana dinyatakan bahwa menggunakan pestisida saja hasilnya sedikit apalagi jika tidak menggunakan pestisida, tanaman bawang tidak bisa dipanen karena dimakan ulat. Meskipun ada keluhan kesehatan yang tidak disukai ataupun yang dirasakan mengganggu seperti pusing ketika mencium bau pestisida dari baju, sepatu dan peralatan menyemprot yang dibawa bapak atau suami mereka pulang ke rumah, pedih dimata seperti katarak apabila terkena pestisida, dan keluar keringat dingin pada saat menyemprot pestisida.

Hasil penelitian ini sesuai dengan pernyataan Luluk dalam penelitiannya bahwa salah satu faktor yang menyebabkan lemahnya hubungan antara sikap dengan praktek petani pada penggunaan pestisida adanya kecemasan yang sangat hebat jika investasi yang mereka tanamkan dalam proses pertanian bawang merah tidak kembali (Sulistyono, 2008). 
Distribusi praktek dan konsentrasi p'pDDE

Berdasarkan hasil penelitian semua responden yang terdeteksi p'pDDE dengan konsentrasi $>0,01 \mathrm{mg} / \mathrm{kg}$ adalah kelompok kategori kurang dalam praktek keamanan penggunaan pestisida. Grafik distribusi praktek dan konsentrasi $p$ ' $p D D E$ cenderung menurun, hal ini menunjukkan bahwa semakin tinggi praktek keamanan bekerja dengan pestisida konsentrasi p'pDDE semakin rendah.

Praktek penggunaan pestisida yang tidak memperhatikan keamanan bekerja secara terus menerus akan berpengaruh pada kesehatan. Praktek keamanan penggunaan pestisida ini meliputi penggunaan alat pelindung diri, kebersihan perorangan, penyimpanan pestisida, dan penyimpanan bawang merah. Peralatan pelindung diri dipersyaratkan digunakan untuk kondisi bekerja dengan pestisida ataupun bekerja di lingkungan yang ada paparan pestisida. Dari wawancara dengan informan triangulasi diketahui bahwa mereka melakukan penyemprotan tanpa memakai masker. Tidak mengherankan jika setiap musim tanam bawang selalu ada kejadian keracunan. Kejadian keracunan seringkali disebabkan oleh ketidakwaspadaan petani akan potensi bahaya yang ada. Masker berfungsi mengurangi potensi absorbsi pestisida melalui pernafasan. Hasil penelitian Siwiendrayanti menunjukkan prevalensi kejadian gangguan fungsi hati pada kelompok WUS yang menggunakan masker lebih besar daripada prevalensi gangguan hati pada kelompok WUS yang tidak pernah memakai masker (Arum, 2010).

Berdasarkan hasil penelitian hanya tiga responden yang menyatakan menggunakan kaos tangan pada saat bekerja di sawah ataupun pada saat memisahkan bawang dari daunnya. Responden merasakan gatal apabila memakai kaos tangan dan pekerjaan memisahkan bawang dari daunnya menjadi lebih lama. Pada saat melakukan pekerjaan membersihkan bawang wanita dapat bersentuhan dengan tanah yang masih menempel pada bawang. Berdasarkan teori bahwa residu pestisida organoklorin pada tanah tidak akan hilang lebih dari beberapa dekade. Praktek bekerja tanpa menggunakan kaos tangan yang memenuhi syarat dapat menjadi potensi masuknya pestisida melalui aborbsi kulit.

Berdasarkan hasil penelitian diketahui tujuh responden menyatakan melakukan kegiatan makan dan minum di area lahan bawang merah pada saat istirahat. Meskipun responden sudah mencuci tangan sebelum makan dan minum, membersihkan diri disawah setelah selesainya pekerjaan tetapi air yang digunakan adalah air sumur di sawah. Sifat organoklorin yang relative stabil secara struktur kimia dan tidak larut dalam air tidak hilang hanya dengan membilas dengan air. Mengganti baju dan menyiram tubuh 
dengan air dan sabun akan lebih dapat menghilangkan zat pencemar yang menempel pada baju dan badan petani.

Berdasarkan hasil penelitian tujuh responden menyatakan menyimpan hasil panen bawang merah yang akan digunakan untuk bibit pada masa tanam berikutnya di dalam rumah yaitu biasanya di dapur, dan dua orang responden menyemprot simpanan tersebut dengan pestisida supaya terhindar dari hama. Frekuensi penyemprotan pada musim hujan lebih sering dilakukan. Dan dari hasil observasi diketahui ada responden yang menyimpan hasil panen bawang di ruang keluarga. Satu ruang dengan melihat televisi, hal ini dilakukan karena keterbatasan ruang. Penempatan hasil panen dan bibit di dalam rumah akan mempengaruhi kesehatan keluarga dalam beraktifitas terutama anakanak. Anak-anak dapat memegang bawang, kontak dengan tanah sawah yang belum dibersihkan pada saat bermain. Praktek ini adalah potensi lain masuknya pestisida dalam tubuh.

\section{Kebiasaan mengkonsumsi ikan}

Semua responden menyatakan mengkonsumsi ikan dalam menu harian mereka. Responden dengan konsentrasi p'pDDE tertinggi menyatakan sering mengkonsumsi ikan hasil memancing di sungai yang merupakan buangan air dari sawah. Informan triangulasi menyatakan bahwa petani sering membuang wadah bekas pestisida dan mencuci peralatan bekas menyemprot di sungai. Sisa -sisa pestisida bisa mencemari air sungai. Selain disebabkan oleh pembuangan wadah bekas pestisida, organoklorin dalam perairan juga dapat berasal dari penyemprotan pestisida ke udara yang terbawa oleh angin dan masuk ke aliran sungai.

$D D T$ yang mempunyai kelarutan rendah dalam air akan diserap oleh partikel dalam air dan menetap di sedimen. Waktu paruh DDT di lingkungan perairan bisa mencapai 150 tahun. DDT dari air yang tercemar dan sedimentasi pada sungai dapat diserap oleh mikroplankton. Karena sifatnya yang persisten, konsentrasi didalam tubuh mikroplankton akan meningkat sampai puluhan kali. Begitu pula ikan sebagai organisme pemangsa mikroplankton mempunyai konsentrasi organoklorin beberapa ratus kali lebih besar daripada di air. Ikan cenderung mengumpulkan DDT pada jaringan lemak mereka. Karena struktur kimianya yang stabil DDT tidak mudah terurai oleh pemanasan maupun reaksi kimia. Manusia sebagai organisme teratas dalam rantai makanan akan mempunyai resiko paling tinggi paparan pestisida melalui makanan atau ikan yang tercemar (US Public Health Service, 2002)

\section{Organoklorin pada wanita yang tidak terlibat di pertanian}


Berdasarkan penelitian diketahui tiga responden yang tidak terlibat di pertanian terdeteksi p'pDDE meskipun dengan konsentrasi cukup rendah yaitu $<0,01 \mathrm{mg} / \mathrm{kg}$. Wanita yang tinggal di daerah pertanian beresiko terpapar pestisida dari lingkungan yang sebagian besar lahan pertanian bawang merah. Dari hasil observasi dan wawancara diketahui ada satu responden yang dibelakang rumahnya lahan pertanian bawang merah. Pada saat dilakukan penyemprotan, udara yang mengandung pestisida tertiup angin masuk ke dalam rumah. Penghuni rumah yang terdiri dari orang tua dengan anak yang masih kecil mengeluh mencium bau obat yang membuat sesak. Paparan pestisida pada wanita yang tidak bekerja di pertanian juga berasal dari kebiasaan petani memilah, membersihkan dan menjemur bawang merah di halaman ataupun juga teras rumah. Kegiatan ini biasanya dilakukan oleh 2 sampai 3 orang wanita di pekarangan dan teras rumah, tidak jarang tetangga berkumpul disekitarnya untuk sekedar melihat ataupun ikut mengobrol. Angin dapat membawa pestisida yang menempel di permukaan bawang ke lingkungan di sekitarnya. DDT bersifat dapat terbawa oleh udara sampai jauh. Masyarakat di daerah pedesaan umumnya mengkonsumsi produk dari lingkungan sekitar mereka, seperti kebiasaan membuat sayur menggunakan daun bawang dalam masakan sehari-hari. Hal ini menyebabkan mereka berada pada resiko yang lebih tinggi dari penggunaan pestisida di pertanian dan terkontaminasi pestisida secara tidak langsung.

\section{Kebijakan pengawasan penggunaan pestisida}

Pengawasan penggunaan pestisida telah dilakukan oleh dinas pertanian dengan memberikan penyuluhan mengenai bagaimana bekerja dengan pestisida meliputi dosis, alat pelindung diri dan pembuangan limbah pestisida. Dan dilanjutkan observasi ke sawah. Tetapi tidak semua petani di desa Tegalgandu bergabung dengan kelompok tani. Pelatihan dan pelayanan yang berhubungan dengan hal-hal yang baru sangatlah penting. Pengetahuan dapat membuat petani menjadi lebih memperhatikan resiko paparan pestisida dan pada akhirnya dapat merubah sikap dan perilakunya terhadap potensi bahaya yang ada (Sulistyono,2008).

Berdasarkan hasil wawancara dengan tokoh masyarakat diketahui bahwa setiap musim tanam ada kejadian keracunan pestisida yang menyebabkan petani pingsan dan dibawa ke rumah sakit. Hal ini menunjukkan bahwa tidak semua petani bawang merah telah mempunyai pengetahuan yang sama mengenai pestisida. Hal ini juga ditunjukkan dengan tidak adanya pengolahan limbah pestisida dengan baik. Wadah wadah bekas pestisida dibuang di 
sungai maupun areal sawah yang pada pada sampel ASI dan juga sebagaimana akhirnya menimbulkan pencemaran dinyatakan oleh informan triangulasi bahwa lingkungan tanah dan juga perairan.

Kebijakan pelarangan beredarnya pada saat ini sudah tidak ada yang menjual $D D T$. Konsentrasi $p$ 'pDDE yang ditemukan organoklorin sejak tahun 1990 terbukti telah pada penelitian ini juga lebih rendah berhasil menurunkan paparan DDT sebagaimana hasil penelitian yang 1994.

menunjukkan tidak terdeteksinya $p^{\prime} p D D T$

Berikut disajikan grafik distribusi karakteristik responden dan konsentrasi $p$ ' $p D D E$ :

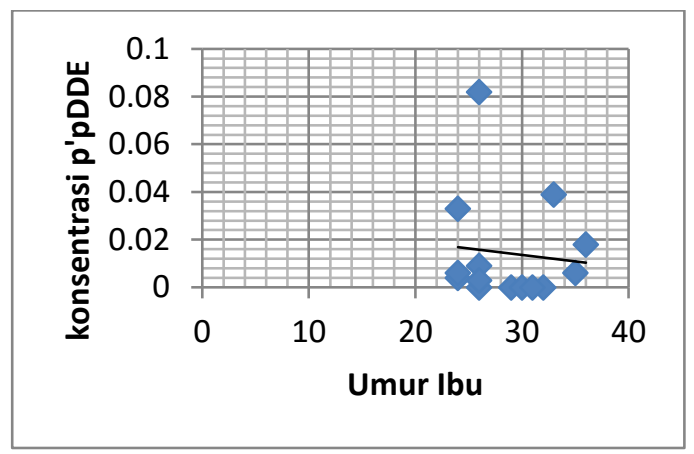

Grafik 1 Distribusi umur ibu dan konsentrasi $p$ 'Pdde

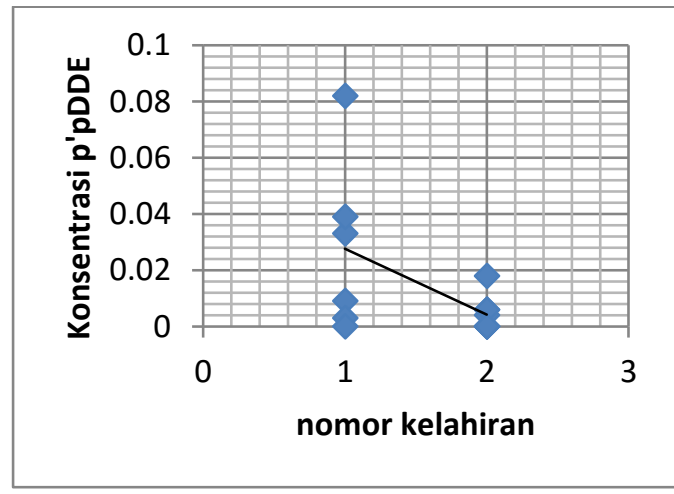

Grafik 2 Distribusi nomor kelahiran dan konsentrasi $p$ 'pDDE 
Kandungan Pestisida Organoklorin...... (Dwi Cahyaningrum, Hanifa MD, M. Sakundarno A)

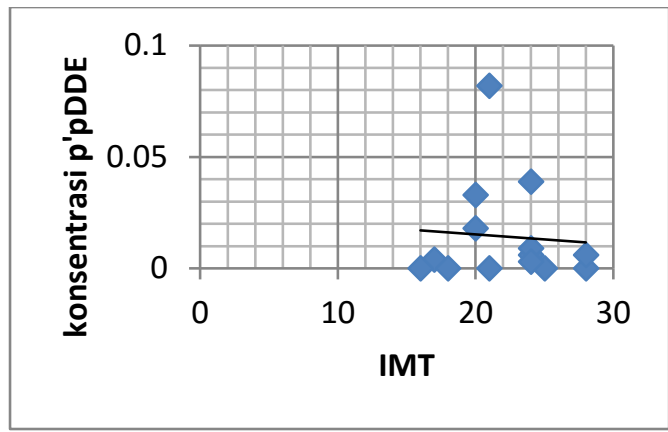

Grafik 3 Distribusi IMT dan konsentrasi p'pDDE

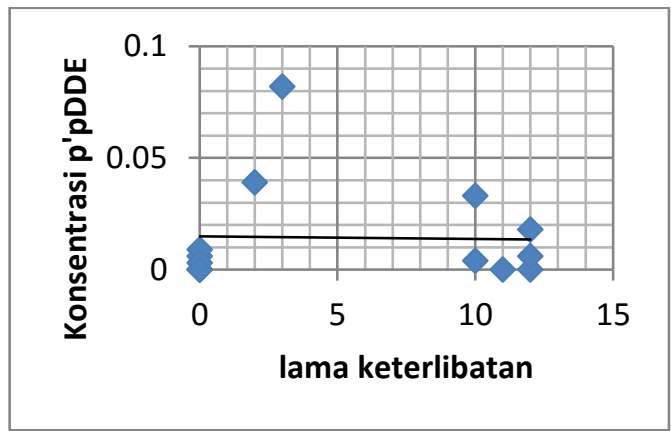

Grafik 4 Distribusi lama terlibat dan konsentrasi $p$ 'Pdde

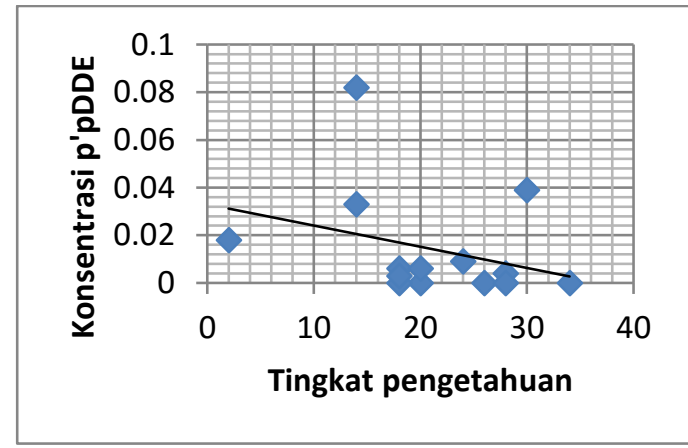

Grafik 5 Distribusi tingkat pengetahuan dan konsentrasi $p$ 'pDDE

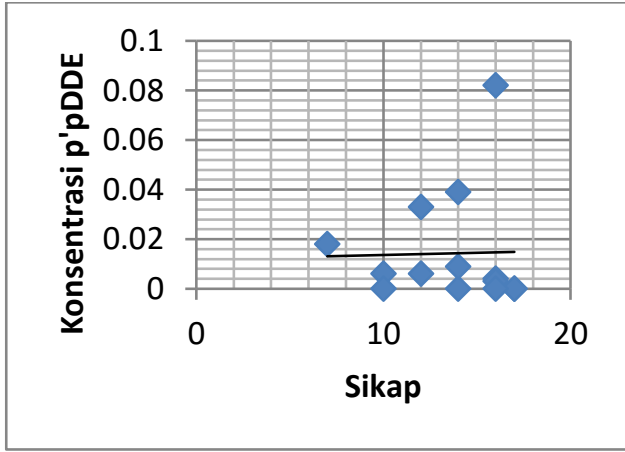

Grafik 6 Distribusi sikap dan konsentrasi $p$ 'pDDE 


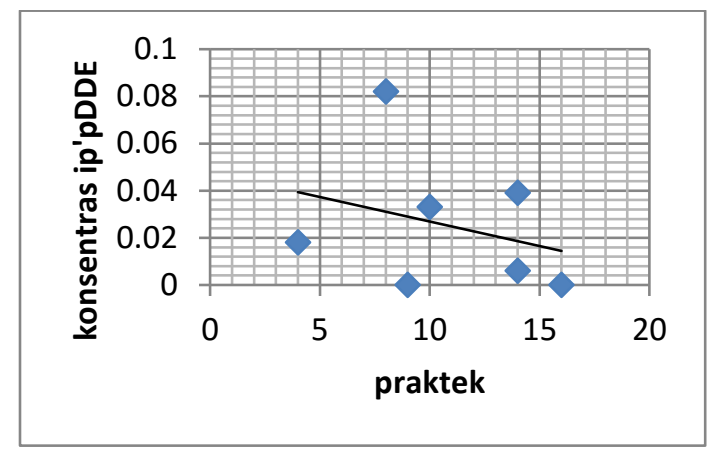

Grafik 7 Distribusi praktek dan konsentrasi $p$ ' $p D D E$

\section{SIMPULAN}

Berdasarkan hasil penelitian diketahui $p ' p D D E$ terdeteksi dengan konsentrasi $>0,01 \mathrm{mg} / \mathrm{kg}$ pada empat air susu ibu dan Dieldrin terdeteksi dengan konsentrasi $<0,01 \mathrm{mg} / \mathrm{kg}$ pada sebelas sampel air susu ibu di pertanian bawang merah Kabupaten Brebes.

Keterlibatan wanita di pertanian bawang merah pada proses pemeliharaan tanaman serta pengolahan hasil panen berpotensi adanya $p^{\prime} p D D E$ dalam air susu Ibu.

Semakin meningkat umur, nomor kelahiran, Indeks Massa Tubuh, tingkat pengetahuan, dan praktek keamanan bekerja dengan pestisida, konsentrasi $p^{\prime} p D D E$ semakin rendah. Perubahan lama keterlibatan di pertanian dan sikap pada keamanan bekerja dengan pestisida tidak menyebabkan perubahan pada konsentrasi p'pDDE pada responden.

Kebiasaan makan ikan darat yang tercemar DDT berpotensi menyebabkan konsentrasi $p$ 'pDDE pada air susu Ibu paling tinggi dibandingkan konsentrasi $p^{\prime} p D D E$ pada air susu Ibu lainnya.

Air susu Ibu yang tidak terlibat di pertanian mempunyai konsentrasi $p ' p D D E$ jauh lebih rendah dibandingkan dengan konsentrasi $p$ ' $p D D E$ dalam air susu ibu yang terlibat di pertanian.

Kebijakan pengawasan penggunaan pestisida yang telah dilaksanakan pada saat ini di daerah pertanian Kabupaten Brebes belum secara efektif meningkatkan keamanan bekerja dengan pestisida pada semua petani hal ini ditunjukkan dengan adanya kejadian keracunan pestisida setiap musim tanam bawang merah.

\section{KEPUSTAKAAN}

Alfian. Faktor yang berhubungan dengan kejadian keracunan pestisida pada petani penyemprot di area pertanian Rasau Jaya Kabupaten Kubu Raya Provinsi Kalimantan Barat (Tesis). Semarang: Magister Kesehatan 
Kandungan Pestisida Organoklorin...... (Dwi Cahyaningrum, Hanifa MD, M. Sakundarno A)

Lingkungan Program Pasca Sarjana Universitas Diponegoro; 2011.

Arum S. Hubungan riwayat pajanan pestisida dengan kejadian gangguan fungsi hati studi pada wanita usia subur di Kecamatan Kersana Kabupaten Brebes (Tesis). Semarang: Magister Kesehatan Lingkungan Program Pasca Sarjana Universitas Diponegoro; 2010.

Bedi. J S. Pesticide residues in human breast milk: Risk assessment for infants from Punjab, India. Elsevier ;2013.

Denny $\mathrm{H}$ M. The association between pesticide exposure and spontaneous abortion in Brebes, Central Java Indonesia. Thesis; 1999.

Mimin K. Faktor-faktor yang berhubungan dengan keracunan pestisida golongan organophiosphat dan Karbamat pada petani penyemprot tembakau di desa Cikawao Kecamatan pacet Kabupaten Bandung.Tesis. Semarang: Magister Kesehatan Lingkungan Fakultas Kesehatan Masyarakat Universitas Diponegoro;2015.

Mishra, Sharma. Assesment of organoklorin pesticides in human milk and risk exposure to infants from North-East India. Elsevier ;2013.

Pemprov Jawa Tengah. Profil Kesehatan Provinsi Jawa Tengah Tahun 2015. Available at http//www.depkes.go.id
Robson. Pest Control and Pesticides: Environmental Health From Global to Local. Second Edition;2010.

Sulistiyono. Pengetahuan Sikap dan Tindakan Petani Bawang Merah dalam Penggunaan Pestisida. J Angroland; 2008.

Timothy C M. Bryan B. Pesticide Toxicology and International Regulation. John Wiley \& sons, Ltd; 2004.

US Departement of Health and Human Services. Toxicological Profile for DDT,DDE and DDD.Public Health Services. 2002. 